\title{
PENGARUH PELAKSANAAN FLUSHING TERHADAP PENGURANGAN VOLUME AIR DAN SEDIMEN DI WADUK MRICA
}

\section{THE EFFECT OF IMPLEMENTATION FLUSHING ON WATER VOLUME AND SEDIMENT REDUCTION IN THE MRICA RESERVOIR}

\author{
Teguh Marhendi ${ }^{1}$, Dani Suryana ${ }^{2}$ \\ ${ }^{12}$ Program Studi Teknik Sipil, Fakultas Teknik dan Sains \\ Universitas Muhammadiyah Purwokerto
}

Informasi Artikel

Dikirim,

Direvisi,

Diterima,

\section{Korespondensi Penulis:}

Teguh Marhendi

Program Studi Teknik Sipil Fakultas Teknik dan Sains

Universitas Muhammadiyah Purwokerto

JL. K.H. Ahmad Dahlan

Purwokerto, 53182

Email: tmarhendi@gmail.com

\begin{abstract}
ABSTRAK
Waduk Mrica merupakan salah satu waduk di Indonesia yang terus mengalami problematik terkait peningkatan sedimentasi. Sampai dengan tahun 2017, total sedimen yang masuk ke waduk telah mencapai 114 juta $\mathrm{m}^{3}$. Angka ini di satu sisi sudah mencapai kapasitas dead storage dari waduk tersebut dan dianggap telah mengganggu kinerja operasional waduk. Berbagai upaya terus dilakukan oleh manajemen waduk utnuk mengurangi peningkatan sedimentasi. Upaya yang sering dilakukan adalah dengan melakukan flushing untuk membuang sedimen yang masuk dan mengurangi rsiko terhadap operasional PLTMH di waduk tersebut. Paper ini dimaksudkan untuk menganalisis pengaruh upaya flushing di waduk Mrica terhadap resiko pengurangan volume air terbuang dibandingkan dengan volume sedimen yang terbuang. Metode yang diterapkan dalam analisis ini menggunakan analisis statistika untu melihat hubungan dalam upaya pengurangan sedimen dan volume air yang terbuang dalam kurun waktu tertentu. Hasil penelitian ini menunjukkan bahwa jumlah volume air yang terbuang jauh lebih besar dibandingkan volume sedimen yang ikut terbuang pada saat pelaksanaan flushing. Total volume sedimen yang terbuang kurun waktu 2009-2018 dan prediksi

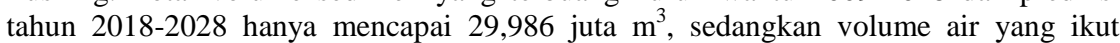
terbuang di kurun waktu tersebut mencapai 971,817 juta $\mathrm{m}^{3}$.
\end{abstract}

Kata Kunci : Flushing, Volume air, Volume sedimen, Waduk Mrica

ABSTRACT

Mrica Reservoir is one of the reservoirs in Indonesia which continues to experience problems related to increased sedimentation. As of 2017, the total sediment entering the reservoir has reached 114 million $\mathrm{m}^{3}$. This figure has reached the dead storage capacity of the reservoir and is considered to have disrupted the operational performance of the reservoir. Reservoir management continues to make efforts to reduce increased sedimentation. Efforts that are often made are flushing to remove incoming sediment and reduce the risk to the operation of the MHP in the reservoir. This paper is intended to analyze the effect of flushing in the Mrica reservoir on the risk of reducing the volume of wasted water compared to the volume of sediment wasted. The method applied in this analysis uses statistical analysis to see the relationship in efforts to reduce sediment and the volume of water wasted within a certain period of time. The results of this study indicate that the volume of water wasted is much greater than the volume of sediment that is wasted during the flushing. The total volume of sediment wasted during the period 2009-2018 and the predictions for 2018-2028 only reached 29,986 million $\mathrm{m}^{3}$, while the volume of water wasted during that period reached 971,817 million $\mathrm{m}^{3}$.

Keyword : Flushing, Water volume, sediment volume, Mrica Reservoir 


\section{PENDAHULUAN}

Permasalahan sedimentasi waduk menjadi permasalahan umum pada waduk-waduk yang ada di Indonesia. Erosi lahan yang tinggi menyebabkan peningkatan produksi sedimen dan berdampak pada pengurangan kapasitas maupun umur fungsi waduk. Beberapa waduk di Indonesia umumnya mengalami permasalahan operasional tersebut dengan meningkatnya sedimentasi sepanjang tahun. Sedimentasi pada waduk juga menyebabkan berkurangnya kapasitas tampungan waduk yang berdampak pada kapasitas pengendalian banjir, produksi listrik dan pangan (Marhendi, T., 2013).

Kejadian erosi lahan memberikan dampak langsung maupun tidak langsung, baik terhadap Daerah Aliran Sungai (DAS) waduk maupun terhadap manusia atau lingkungan sekitar Waduk Mrica. Erosi yang terjadi terusmenerus menyebabkan kerusakan struktur tanah yang berdampak pada lahan pertanian, perkebunan serta menyebabkan operasinal waduk menjadi terganggu. Sumber utama sedimentasi waduk berasal dari erosi lahan di daerah tangkapan waduk, masalah pokok peningkatan erosi disebabkan terjadi perubahan fungsi hutan di hulu Daearah Aliran Sungai (Marhendi, T, 2013).

Waduk Mrica terletak di Wanadadi Kecamatan Bawang Kabupaten Banjarnegara, juga dikenal dengan Waduk Panglima Soedirman mulai dibangun tahun 1983 dan penggenangannya dimulai sejak bulan April 1988, berakhir pada bulan Oktober 1988, mempunyai luas Daerah Aliran Sungai (DAS) $1022 \mathrm{~km}^{2}$ atau kurang lebih 32 $\%$ dari luas seluruh daerah aliran sungai (DAS) Serayu. Waduk Mrica dibangun dengan umur layanan desain 60 tahun atau fungsinya akan berakhir sekitar tahun 2040. Permasalahan yang timbul dari oprasional Waduk Mrica saat ini salah satunya adalah ancaman pendangkalan waduk sehingga kapasitas tampung semakin berkurang. Menurut data dari PT Indonesia Power sebagai pengelola Waduk Mrica, sedimentasi telah berpengaruh terhadap oprasional waduk, setelah 16 tahun beroperasi laju pengurangan produksi listrik sebesar 18\%. Apabila proses sedimentasi berjalan terus tanpa pengendalian, maka waduk akan semakin cepat dipenuhi oleh sedimen, sehingga umur layannya tidak sesuai dengan umur layan desain dan manfaat waduk akan semakin berkurang (Alfianto, A dan Soewarno, 2014)

Salah satu penyebab Sedimentasi adalah adanya perubahan penggunaan lahan dalam daerah aliran sungai (DAS) yang semakin tidak terkendali. Luas hutan semakin berkurang, lahan pertanian telah banyak yang berubah menjadi daerah perluasan pemukiman, perkotaan dan industri, kerusakan hutan konservasi hingga mencapai 1,6 juta hektar per tahun, menambah kerusakan DAS akibat dari sedimen dan erosi (Hafied, 2006 dalam Alfianto, A., 2014).

Produksi sedimen merupakan kejadian alami yang tidak mungkin dihindari sama sekali. De Cesare. Al (2001), dalam Suroso (2007), menyebutkan tingginya erosi di daerah hulu atau di sub daerah aliran sungai, menyebabkan sedimentasi menjadi tinggi. Sedimen yang tinggi selanjutnya akan mengakibatkan pengurangan kapasitas waduk dan mempengaruhi jumlah ketersediaan air waduk serta berpengaruh terhadap umur layanan waduk (Marhendi, T, 2009).

Kondisi perkembangan sedimentasi Waduk Mrica terus mengalami peningkatan. Hampir sebagian besar dasar waduk dipenuhi sedimen. Sumber sedimen berasal dari erosi Daerah Aliran Sungai Serayu Hulu dan Merawu (PT. Indonesia Power, 2009). Diperkirakan tiap tahun sekitar 4 juta meter kubik sedimen masuk menggenangi waduk (PT. Indonesia Power, 2007). Sedimentasi telah berlangsung sejak tahun pertama operasi yaitu 1988. Sedimentasi yang terjadi tahun 1988 adalah sebesar 3,4 juta $\mathrm{m}^{3}$ atau sekitar $48,35 \%$ dari total volume waduk. Tahun 2006 sedimen yang mengendap di waduk telah mencapai 75 juta $\mathrm{m}^{3}$ atau sekitar 50,58\% volume waduk telah terisi sedimen. Tahun 2010 sedimen yang mengendap di waduk mencapai 92,7 juta $\mathrm{m}^{3}$. Di akhir tahun 2015 sedimen yang mengendap di waduk sudah mencapai $75 \%$ atau sudah mencapai 110,6 juta $\mathrm{m}^{3}$ dan di tahun 2017 sedimen telah mencapai 114 juta $\mathrm{m}^{3}$. Dengan terus bertambahnya sedimen di Waduk Mrica diperkirakan akan berhenti total sebelum waktu yang direncanakan ( Marhendi, T, 2009).

Flushing hanya bisa mengglontorkan sedimentasi yang dekat dengan bukaan pintu air yang menuju ke sungai hilir, sedangkan sedimen lambat laun semakin bertambah dari hulu menuju ke waduk, saat ini sedimen sudah terlalu banyak sehingga terjadi penumpukan sedimen sampai terlihat seperti pembentukan pulau baru. Sedimentasi yang jauh dari pintu bukaan bendungan yang menuju sungai hilir tidak semuanya tergelontorkan sehingga air yang berasal dari hulu makin lama makin berkurang karena air terhambat oleh tumpukan atau banyaknya sedimen di Waduk Mrica, maka penting dilakukan penelitian tentang pengaruh pelaksanaan flushing di Waduk Mrica terhadap pengurangan volume air waduk dan sedimen.

\section{METODE PENELITIAN}

\section{Lokasi Penelitian}

Waduk Mrica berlokasi di Kecamatan Bawang, Kabupaten Banjarnegara, Jawa Tengah pada koordinat $109^{\circ} 06^{\prime} 00^{\prime \prime}-110^{\circ} 07^{\prime} 49^{\prime \prime}$ BT dan $7^{\circ} 17^{\prime} 04^{\prime \prime}-7^{\circ} 47^{\prime} 07^{\prime \prime}$ LS. Tepatnya, sekitar 9 kilo meter arah barat dari pusat kota Banjarnegara-Purwokerto dan berada di desa Karangjambe,Wanadadi, Banjarnegara. 


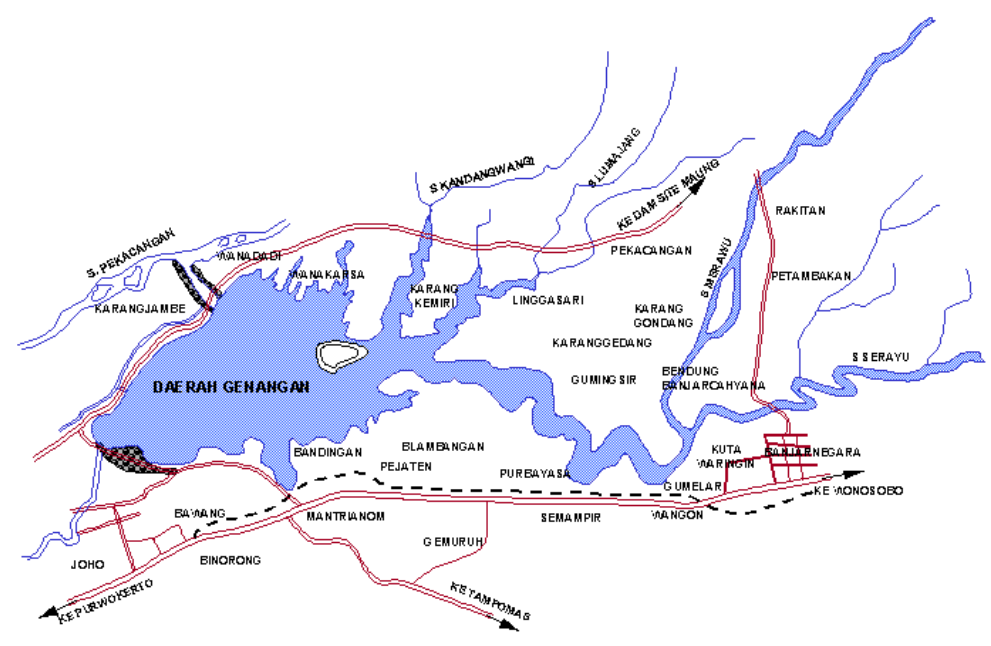

Gambar 3.1 Lay Out Waduk Mrica

Sumber : PT. Indonesia Power, 2010, Marhendi, T. 2009

\section{Pengumpulan Data}

Data yang digunakan untuk Analisis pengaruh pelaksanaan flushing di Waduk Mrica terhadap pengurangan volume air waduk dan sedimen diambil dari data sekunder hasil pengamatan atau pengukuran yang dilakukan oleh PT. Indonesia Power Unit Pembangkitan Mrica Banjarnegara sebagai institusi pengelola PLTA PB. Soedirman, berupa :

1. Data Pelaksanaan flushing dari tahun 2009 sampai dengan 2018.

2. Data Sedimentasi dari tahun 2009 sampai dengan 2018.

3. Data Debit air flushing dari tahun 2009 sampai dengan 2018

\section{Analisis Frekuensi}

Analisis frekuensi dalam hidrologi digunakan untuk memperkirakan curah hujan atau debit rancangan dengan kala ulang tertentu. Analisi frekuensi dalam hidrologi sendiri didefinisikan sebagai perhitungan atau peramalan suatu peristiwa hujan atau debit yang menggunakan data historis dan frekuensi kejadiannya.

\section{Parameter statistik}

Parameter yang digunakan dalam perhitungan analisis frekuensi meliputi parameter nilai rata-rata $(\bar{X})$, deviasi standar (S), koefisien variasi $(\mathrm{Cv})$, koefisien kemencengan (Cs) dan koefisien kurtosis (Ck). Sementara untuk mencari harga parameter statistik dilakukan dengan perhitungan rumus dasar antara lain sebagai berikut: (Soemarto, C.D. 1999)

a. Standar Deviasi (Standard Deviation) :

$$
\mathrm{S}=\sqrt{\frac{\sum(\mathrm{Xi}-\overline{\mathrm{X}})^{2}}{\mathrm{n}-1}} .
$$

b. Koefisien Variasi (Variation) :

$$
C v=\frac{S}{\bar{X}}
$$

c. Koefisien Kemencengan (Skewness):

$$
C s=\frac{\sum_{i=1}^{n}(X i-\bar{X})^{3}}{(n-1)(n-2) S^{3}}
$$

d. Koefisien Kurtosis (Curtosis) :

$$
C k=\frac{n^{2} \cdot \Sigma(X i-\bar{X})^{4}}{(n-1)(n-2)(n-3) S^{4}}
$$

dengan:

$\mathrm{Xi} \quad=$ Debit sedimen tahunan (ton/tahun)

$\bar{X} \quad=$ Debit sedimen rata-rata selama 10 tahun (ton/tahun)

$\mathrm{n} \quad=$ Jumlah tahun pencatatan data hujan (pengamatan)

$\mathrm{S} \quad=$ Standar deviasi (simpangan baku) 
$\mathrm{Cv}=$ Koefisien variasi

Cs $\quad=$ Koefisien kemencengan

$\mathrm{Ck} \quad=$ Koefisien kurtosis

\section{Metode Distribusi Log Pearson III}

Metode Log Pearson tipe III apabila digambarkan pada kertas peluang logaritmik akan merupakan persamaan garis lurus, sehingga dapat dinyatakan sebagai model matematik dangan persamaan sebagai berikut :

$$
\begin{aligned}
& \mathrm{Y}=\overline{\mathrm{Y}}+\mathrm{K} . \mathrm{S} \\
& \mathrm{Log} \mathrm{Rt}=\log \mathrm{X}+\mathrm{Gt} \cdot \mathrm{S} \log \mathrm{X} . \\
& \text { (Soewarno, 1995) }
\end{aligned}
$$

dengan:

$$
\begin{array}{ll}
\mathrm{X}, \mathrm{Gt} & =\text { Debit Sedimen Tahunan (Ton/Tahun) } \\
\mathrm{Y} & =\text { Nilai logaritmik dari } \mathrm{X} \text { atau log } \mathrm{X} \text { dengan periode tertentu } \\
\bar{Y} & =\text { Rata-rata hitung nilai } \mathrm{Y} \\
\mathrm{S} \log \mathrm{x} & =\text { Deviasi standar nilai } \mathrm{Y} \\
\mathrm{K} & =\text { Karakteristik distribusi peluang log-pearson tipe III }
\end{array}
$$

Langkah-langkah perhitungan kurva distribusi Log Pearson III adalah :

1) Tentukan logaritma dari semua nilai variasi $X$

2) Hitung nilai rata-ratanya :

$$
\begin{aligned}
& \overline{\log \mathrm{x}}=\frac{\sum \log \mathrm{x}}{\mathrm{n}} \ldots \ldots \ldots \ldots \\
& \text { (CD. Soemarto, 1999) }
\end{aligned}
$$

3) Hitung nilai deviasi standarnya dari $\log \mathrm{X}$ :

$$
\begin{aligned}
& \overline{\mathrm{S} \log \mathrm{x}}=\sqrt{\frac{\sum(\log \mathrm{x}-\overline{\log \mathrm{x}})^{2}}{\mathrm{n}-1}} \\
& \text { (CD. Soemarto, 1999) }
\end{aligned}
$$

4) Hitung nilai koefisien kemencengan

$$
\begin{aligned}
& \mathrm{Cs}=\frac{\mathrm{n} \sum_{\mathrm{i}-1}^{\mathrm{n}}(\log \mathrm{x}-\overline{\log \mathrm{x}})^{3}}{(\mathrm{n}-1)(\mathrm{n}-2)(\overline{\operatorname{sig} \mathrm{x}})^{3}} \\
& \text { (CD. Soemarto, 1999) }
\end{aligned}
$$

Sehingga persamaan garis lurusnya dapat ditulis :

$$
\begin{aligned}
& \log \mathrm{x}=\overline{\log \mathrm{x}}+\mathrm{k}(\overline{\mathrm{s} \log \mathrm{x}}) \\
& \text { (CD. Soemarto, 1999) }
\end{aligned}
$$

5) Menentukan anti $\log$ dari $\log X$, untuk mendapat nilai $X$ yang diharapkan terjadi pada tingkat peluang atau periode tertentu sesuai dengan nilai Cs nya.

\section{Uji Kesesuaian Chi Square}

Uji Chi kuadrat dimaksudkan untuk menentukan apakah persamaan distribusi peluang yang telah dipilih dapat mewakili dari distribusi statistik sampel data yang dianalisis. Uji keselarasan chi square menggunakan rumus :

$$
\begin{aligned}
& \mathrm{X}^{2}=\sum_{\mathrm{i}-1}^{\mathrm{n}} \frac{(\mathrm{oi}-\mathrm{Ei})^{2}}{\mathrm{Ei}} \\
& (\text { Soewarno, 1995) }
\end{aligned}
$$

$$
\begin{aligned}
\text { dengan : } & \\
\mathrm{X}^{2} & =\text { harga chi square terhitung } \\
\mathrm{Oi} & =\text { jumlah nilai pengamatan pada sub kelompok ke-1 } \\
\mathrm{Ei} & =\text { jumlah nilai teoritis pada sub kelompok ke-1 } \\
\mathrm{N} & =\text { jumlah data }
\end{aligned}
$$


Dari hasil pengamatan yang didapat dicari penyimpangannya dengan chi square kritis paling kecil. Untuk suatu nilai nyata tertentu (level of significant) yang sering diambil adalah $5 \%$. Derajat kebebasan ini secara umum dihitung dengan rumus sebagai berikut :

$\mathrm{Dk}=\mathrm{n}-3$

(Soewarno, 1995)

dengan :

$\mathrm{Dk}=$ derajat kebebasan

Analisis hubungan volume air dan sedimen terbuang setelah dilakukan flushing

Analisis ini untuk mengetahui perubahan volume air dan sedimentasi yang terbuang dengan dilakukan penggelontoran sedimentasi (flushing) pada waduk Mrica.

\section{HASIL DAN PEMBAHASAN (Times New Roman 10pt)}

Analisis Volume Sedimen yang terbuang setelah dilakukan Flushing

Analisis Volume Sedimen yang terbuang setelah dilakukan Flushing, diambil dari data tahun 2009-2018 yang diperoleh dari PT. Indonesia Power, yang terdapat pada Tabel 4.1 dibawah ini:

Tabel 1. Data Volume Sedimen yang terbuang setelah dilakukan flushing

\begin{tabular}{cc}
\hline Tahun & Juta $\left(\mathrm{m}^{3}\right)$ \\
\hline 2009 & 0,130 \\
2010 & 0,536 \\
2011 & 0,719 \\
2012 & 1,435 \\
2013 & 1,191 \\
2014 & 1,652 \\
2015 & 1,422 \\
2016 & 3,042 \\
2017 & 0,511 \\
2018 & 0,299 \\
\hline
\end{tabular}

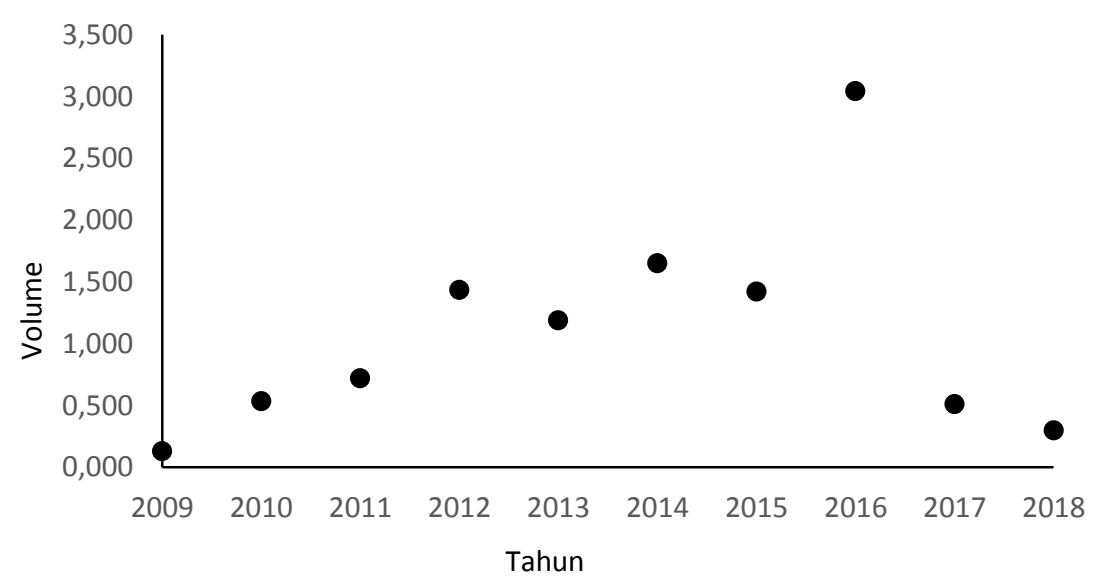

Gambar 4.1 Volume Sedimen yang terbuang setelah dilakukan flushing dari Tahun 2009-2018

\section{Parameter Statistik Volume Sedimen yang terbuang setelah dilakukan Flushing}

Parameter Statistik Volume Sedimen yang terbuang setelah dilakukan Flushingyang perlu diperkirakan untuk pemilihan distribusi yang sesuai dengan sebaran data. Besarnya parameter nilai, dapat diukur yakni melalui perhitungan parameter statistik untuk mencari $(\mathrm{Xi}-\mathrm{X}),(\mathrm{Xi}-\mathrm{X})^{2},(\mathrm{Xi}-\mathrm{X})^{3},(\mathrm{Xi}-\mathrm{X})^{4}$.

dengan :

$$
\begin{aligned}
& X i=\text { volume sedimen }\left(\mathrm{m}^{3}\right) \\
& \bar{X}=\text { volume sedimen rerata }\left(\mathrm{m}^{3}\right)
\end{aligned}
$$


Berikut ini adalah data perhitungan Parameter Statistik Volume Sedimen yang terbuang setelah dilakukan Flushing yang dapat dilihat pada Tabel 4.2 dibawah ini:

Tabel 2. Parameter Statistik Volume Sedimen yang terbuang setelah dilakukan Flushing

\begin{tabular}{crrrrr}
\hline Tahun & Juta $\left(\mathrm{m}^{3)}\right.$ & \multicolumn{1}{c}{$(\mathrm{Xi}-\mathrm{X})$} & \multicolumn{1}{c}{$(\mathrm{Xi}-\mathrm{X})^{2}$} & \multicolumn{1}{c}{$(\mathrm{Xi}-\mathrm{X})^{3}$} & \multicolumn{1}{c}{$(\mathrm{Xi}-\mathrm{X})^{4}$} \\
\hline 2009 & 0,130 & $-0,964$ & $-0,929$ & $-0,895$ & $-0,863$ \\
2010 & 0,536 & $-0,558$ & $-0,311$ & $-0,174$ & $-0,097$ \\
2011 & 0,719 & $-0,375$ & $-0,140$ & $-0,053$ & $-0,020$ \\
2012 & 1,435 & 0,341 & 0,116 & 0,040 & 0,014 \\
2013 & 1,191 & 0,097 & 0,009 & 0,000 & 0,000 \\
2014 & 1,652 & 0,558 & 0,311 & 0,174 & 0,097 \\
2015 & 1,422 & 0,328 & 0,108 & 0,035 & 0,012 \\
2016 & 3,042 & 1,948 & 3,795 & 7,392 & 14,409 \\
2017 & 0,511 & $-0,583$ & $-0,340$ & $-0,198$ & $-0,115$ \\
2018 & 0,299 & $-0,795$ & $-0,632$ & $-0,502$ & $-0,399$ \\
\hline Jumlah & 10,937 & 0 & 1,987 & 5,819 & 13,038 \\
X & 1,094 & & & & \\
Sumber : Analisis, 2019 & & & & &
\end{tabular}

Bentuk perhitungan Parameter Statistik Volume Sedimen yang terbuang setelah dilakukan Flushing antara lain sebagai berikut :

a. Standar Deviasi (Standart Deviation)

Menggunakan persamaan (10)

$S=\sqrt{\frac{\sum(X i-X)^{2}}{n-1}}=\sqrt{\frac{1,987}{10-1}}=0,469$

b. Koefisien Variasi (Variation)

Menggunakan persamaan (11)

$C v=\frac{S x}{X}$

$C v=\frac{0,469}{1,094}=0,428$

c. Koefisien Kemencengan (Skewness)

Menggunakan persamaan (12)

$C s=\frac{\sum_{i=1}^{n}(X i-X)^{3}}{(n-1)(n-2) S^{2}}$

$C s=\frac{10 \times 5,819}{(10-1) \times(10-2) \times 0,219}=0,369$

d. Koefisien Kurtosis (Curtosis)

Menggunakan persamaan (13)

$C k=\frac{n^{2} \cdot \sum(X i-X)^{4}}{(n-1) x(n-2) x(n-3) S^{4}}$

$C k=\frac{10^{2} \cdot 13,038}{(10-1) x(10-2) x(10-3) x 0,048}=\frac{1303,8}{24,384}=53,894$

\section{Analisis Kesesuaian Distribusi}

Analisis Kesesuaian Distribusi berguna untuk memperkuat perkiraan distribusi yang kita ambil, maka dilakukan uji kesesuaian distribusi, yaitu Chi-kuadrat pada Tabel 4.3 dibawah ini:

Tabel 3. Hasil Uji Distribusi Statistik

\begin{tabular}{ccclc}
\hline No & Jenis Distribusi & Syarat & Hasil Hitungan & Kesimpulan \\
\hline \multirow{2}{*}{1} & \multirow{2}{*}{ Normal } & $\mathrm{Cs} \approx 0$ & $\mathbf{C s}=\mathbf{0 , 7 2 6}$ & \multirow{2}{*}{ Tidak memenuhi } \\
& & $\mathrm{Ck} \approx 3$ & $\mathbf{C k}=\mathbf{5 3 , 8 9 4}$ & \\
\hline
\end{tabular}

CIVeng Vol.1, No.2, Juli 2020 : 55 68 


\begin{tabular}{cllll}
\hline 2 & Log Normal & $\mathrm{Cs} \approx \mathrm{Cv}$ & $\mathbf{C s}=\mathbf{0 , 4 2 8}$ & Tidak memenuhi \\
3 & Log Person III & $\mathrm{Cs} \neq 0$ & $\mathbf{C s}=\mathbf{0 , 7 2 6}$ & Memenuhi \\
& & $\mathrm{Cs} \leq 1,1396$ & $\mathbf{C s}=\mathbf{0 , 7 2 6}$ & \multirow{2}{*}{ Tidak memenuhi } \\
\hline & Gumbel & $\mathrm{Ck} \leq 5,4002$ & $\mathbf{C k}=\mathbf{5 3 , 8 9 4}$ & \\
\hline \multicolumn{2}{l}{ Sumber $:$ C.D. Soemarto, 1999} &
\end{tabular}

Dari perhitungan perbandingan syarat dan hasil perhitungan, maka didapatkan distribusi yang dapat digunakan adalah Distribugi Log Person III dengan nilai $\mathrm{Cs}=0,726$ sesuai dengan syarat $\mathrm{Cs} \neq 0$.

Untuk menghitung volume sedimen yang terbuang setelah dilakukan flushing menggunakan beberapa persamaan sebagai berikut:

Nilai Rata-rata

$\overline{\log x}=\frac{\sum \log X i}{n}=\frac{-1,040}{10}=-0,104$

Standar Deviasi

$S=\sqrt{\frac{\sum(\log X r-\overline{\log X \imath})^{2}}{n-1}}=\sqrt{\frac{1.152}{10-1}}=0.357$

Nilai Koefisien Kemencengan

$$
\begin{aligned}
C S & =\frac{\sum_{i=1}^{n}(\log X r-\log X i)^{3}}{(n-1)(n-2) S^{2}} \\
& =\frac{10 \times 0,664}{(10-1) \times(10-2) \times 0.127}=0,726
\end{aligned}
$$

Tabel 4. Perhitungan Distribusi Metode Log Person III

\begin{tabular}{cccccc}
\hline Tahun & Juta $\left(\mathrm{m}^{3}\right)$ & $\log \mathrm{Xi}$ & $\log \mathrm{Xr}-\log \mathrm{Xi}$ & $(\log \mathrm{Xr}-\log \mathrm{Xi})^{2}$ & $(\log \mathrm{Xr}-\log \mathrm{Xi})^{3}$ \\
\hline 2009 & 0,130 & $-0,877$ & 0,915 & 0,855 & 0,625 \\
2010 & 0,536 & $-0,270$ & 0,308 & 0,094 & 0,000 \\
2011 & 0,719 & $-0,143$ & 0,182 & 0,033 & 0,000 \\
2012 & 1,435 & 0,156 & $-0,117$ & $-0,013$ & 0,000 \\
2013 & 1,191 & 0,075 & $-0,036$ & 0,000 & 0,000 \\
2014 & 1,652 & 0,217 & $-0,178$ & $-0,031$ & 0,000 \\
2015 & 1,422 & 0,152 & $-0,113$ & $-0,012$ & 0,000 \\
2016 & 3,042 & 0,483 & $-0,444$ & $-0,197$ & 0,007 \\
2017 & 0,511 & $-0,291$ & 0,329 & 0,108 & 0,001 \\
2018 & 0,299 & $-0,524$ & 0,562 & 0,315 & 0,031 \\
\hline Jumlah & 10,937 & $-1,040$ & 1,408 & 1,152 & 0.664 \\
Xr & 1,093 & & & &
\end{tabular}

\section{Uji Kesesuaian Distribusi}

Diperlukan penguji parameter untuk menguji kecocokan distribusi frekuensi sampel data terhadap fungsi distribusi peluang yang diperkirakan dapat menggabarkan atau mewakili distribusi perwakilan tersebut (Suripin, 2004:57). Parameter yang sering digunakan adalah:

Untuk menguji keselarasan distribusi yang kita ambil dengan ujiChi-Kuadrat menggunakan persamaan (3.4) sebagai berikut :

$$
\begin{aligned}
\mathrm{X}^{2} & =\sum_{\mathrm{i}-1}^{\mathrm{n}} \frac{(\mathrm{oi}-\mathrm{Ei})^{2}}{\mathrm{Ei}} \\
\text { dengan }: & \\
\mathrm{K} & =1+3.322 \log \mathrm{n} \\
& =1+3.322 \log 10=4,322 \approx 4
\end{aligned}
$$

Menggunakan persamaan (3.5)

$$
\mathrm{Dk}=\mathrm{k}-(1+1)
$$


$=4-(2)$

$=2$

$$
\begin{aligned}
E i & =\frac{n}{k}=\frac{10}{4}=2.50 \\
D x & =\frac{X \max -X \min }{k-1} \\
& =\frac{(3.042-0,130)}{3}=0,970
\end{aligned}
$$

$\mathrm{X}$ awal $=\mathrm{Xmin}-(0.5 \times \mathrm{Dx})$

$$
=0,130-(0.5 \times 0,970)=-0,355
$$

dengan:

$\mathrm{K} \quad=$ jumlah kelas

$\mathrm{N} \quad=$ jumlah data

$\mathrm{Dk}=$ derajat kebebasan

Xawal = batas awal kelas

Nilai $\mathrm{X}^{2} \mathrm{cr}$ dicari dari Tabel dengan nilai $\mathrm{Dk}=2$ dan derajat kepercayaan 5\%. Kemudian bandingkan nilai $\mathrm{X}^{2}$ dengan melihat Tabel 4.7 dengan syarat $\mathrm{X}^{2} \leq \mathrm{X}^{2} \mathrm{cr}$ (Soewarno, 1995).

$$
\begin{array}{ll}
\text { Derajat Kepercayaan }(\propto) & =5 \% \\
\mathrm{X}^{2} & =3,6 \\
\mathrm{X}^{2} \mathrm{cr}(\text { Tabel 4.15) } & =5,991
\end{array}
$$

Berdasarkan hasil perbandingan diatas yang menyatakan bahwa $X^{2}<X^{2} c r$, maka hipotesa pengujian dapat diterima.

\section{Analisis Volume Air yang terbuang setelah dilakukan Flushing}

Analisis Volume Air yang terbuang setelah dilakukan flushing diambil dari data tahun 2009-2018 yang diperoleh dari PT. Indonesia Power, yang terdapat pada Tabel 4.8 dibawah ini:

Tabel 5. Data Volume Air yang terbuang setelah dilakukan flushing

\begin{tabular}{cr}
\hline Tahun & Juta $\left(\mathrm{m}^{3}\right)$ \\
\hline 2009 & 7,000 \\
2010 & 18,000 \\
2011 & 26,000 \\
2012 & 39,000 \\
2013 & 34,000 \\
2014 & 25,000 \\
2015 & 11000 \\
2016 & 119,000 \\
2017 & 25,000 \\
2018 & 19,000 \\
\hline Sumber : PT. Indonesia Power, 2019
\end{tabular}

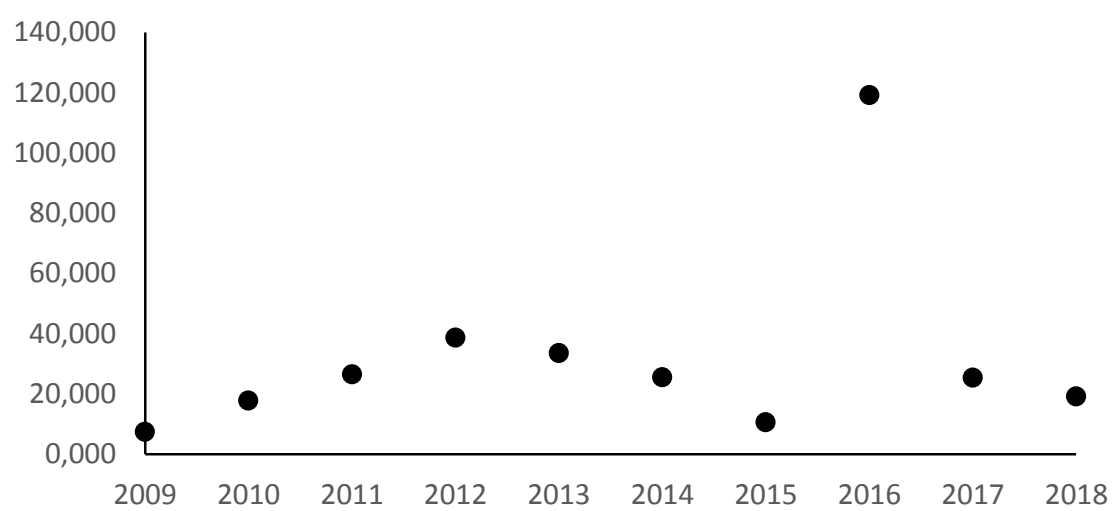

Gambar 4.2 Volume Air yang terbuang setelah dilakukan Flushing dari Tahun 2009-2018 


\section{Parameter Statistik Volume Air yang terbuang setelah dilakukan Flushing}

Parameter Statistk Volume Air yang terbuang setelah dilakukanFlushing yang perlu diperkirakan untuk pemilihan distribusi yang sesuai dengan sebaran data. Besarnya parameter nilai, dapat diukur yakni melalui perhitungan parameter statistik untuk mencari $(\mathrm{Xi}-\mathrm{X}),(\mathrm{Xi}-\mathrm{X})^{2},(\mathrm{Xi}-\mathrm{X})^{3},(\mathrm{Xi}-\mathrm{X})^{4}$

Dimana :

$X i=$ volume Air $\left(\mathrm{m}^{3}\right)$

$\bar{X}=$ volume Air rerata $\left(\mathrm{m}^{3}\right)$

Berikut ini adalah data perhitungan Parameter Statistik Volume Air yang terbuang setelah dilakukan Flushing, dapat dilihat pada tabel 4.9 dibawah ini.

Tabel 6. Parameter Statistik Volume Air yang terbuang setelah dilakukan Flushing

\begin{tabular}{crrrrr}
\hline Tahun & Juta $\left(\mathrm{m}^{3}\right)$ & \multicolumn{1}{c}{$(\mathrm{Xi}-\mathrm{X})$} & \multicolumn{1}{c}{$(\mathrm{Xi}-\mathrm{X})^{2}$} & \multicolumn{1}{c}{$(\mathrm{Xi}-\mathrm{X})^{3}$} & \multicolumn{1}{c}{$(\mathrm{Xi}-\mathrm{X})^{4}$} \\
\hline 2009 & 7,000 & $-25,300$ & $-640,090$ & $-16194,277$ & $-409715,208$ \\
2010 & 18,000 & $-14,300$ & $-204,490$ & -2.924 .207 & $-41816,16$ \\
2011 & 26,000 & $-6,300$ & $-39,690$ & $-250,047$ & $-1575,296$ \\
2012 & 39,000 & 6,700 & 44,690 & 300,763 & 2015,112 \\
2013 & 34,000 & 1,700 & 2,890 & 4,913 & 8,352 \\
2014 & 25,000 & $-7,300$ & $-53,290$ & $-389,017$ & $-2839,824$ \\
2015 & 11000 & $-21,300$ & $-453,690$ & $-9663,597$ & $-205834,616$ \\
2016 & 119,000 & 86,700 & 7516,890 & 651714,363 & 56503635,27 \\
2017 & 25,000 & $-7,300$ & $-53,290$ & $-389,017$ & $-2839,824$ \\
2018 & 19,000 & $-13,300$ & $-176,890$ & $-2352,637$ & $-31290,072$ \\
\hline Jumlah & 323 & 0 & 5943,24 & 619857,24 & 53722014,74 \\
X & 32 & & & & \\
\hline Sumber : Analisis, 2019 & & & & &
\end{tabular}

Bentuk perhitungan Parameter Statistik Volume Air yang terbuang setelah dilakukanFlushing antara lain sebagai berikut :

a. Standar Deviasi (Standart Deviation)

Menggunakan persamaan (10)

$S=\sqrt{\frac{\sum(X i-X)^{2}}{n-1}}=\sqrt{\frac{5943,24}{10-1}}=25,697$

b. Koefisien Variasi (Variation)

Menggunakan persamaan (11)

$C v=\frac{S x}{X}$

$C v=\frac{25,697}{32,3}=0,796$

c. Koefisien Kemencengan (Skewness)

Menggunakan persamaan (12)

$$
\begin{aligned}
C s & =\frac{\sum_{i=1}^{n}(X i-X)^{3}}{(n-1)(n-2) S^{2}} \\
C s & =\frac{10 \times 619857,24}{(10-1) \times(10-2) \times 660,335}=0,130
\end{aligned}
$$

d. Koefisien Kurtosis (Curtosis)

Menggunakan persamaan (13)

$$
\begin{aligned}
C k & =\frac{n^{2} \cdot \sum(X i-X)^{4}}{(n-1)(n-2)(n-3) S^{4}} \\
C k & =\frac{10^{2} \times 53722014,74}{(10-1) x(10-2) x(10-3) \times 436043,38}=24,445
\end{aligned}
$$


Analisis Prediksi Volume Sedimen dan Air terbuang setelah flushing 10 tahun Mendatang.

Analisis ini digunakan untuk memperkirakan frekuensi suatu kejadian pada masa lalu dan masa yang akan datang. Berdasarkan hasil perhitungan volume sedimen dan volume air yang terjadi di waduk Mrica selama 10 tahun sebelumnya yang mengalami kenaikan dan penurunan pada tahun-tahun tertentu. Dengan hal tersebut dapat diketahui apakah ada kemungkinan terulangnya volume sedimen dan volume air untuk 10 tahun yang akan datang.

Dari hasil analisis perhitungan volume sedimen dan volume air yang terbuang setelah dilakukan flushing 10 tahun terakhir makadapat di prediksi volume sedimen dan volume air yang terbuang untuk 10 tahun mendatang, maka didapatkan hasil berupa data dalam bentuk tabel dan grafik dibawah ini:

Tabel 7. Volume Sedimen terbuang setelah Flushing Tahun 2009-2018 dan prediksi tahun 2019-2028

\begin{tabular}{cc}
\hline Tahun & $\begin{array}{c}\text { Volume Sedimen } \\
\text { Juta }\left(\mathrm{m}^{3}\right)\end{array}$ \\
\hline 2009 & 0,130 \\
2010 & 0,536 \\
2011 & 0,719 \\
2012 & 1,435 \\
2013 & 1,191 \\
2014 & 1,652 \\
2015 & 1,422 \\
2016 & 3,042 \\
2017 & 0,511 \\
2018 & 0,299 \\
2019 & 1,541 \\
2020 & 1,622 \\
2021 & 1,703 \\
2022 & 1,784 \\
2023 & 1,865 \\
2024 & 1,946 \\
2025 & 2,026 \\
2026 & 2,107 \\
2027 & 2,188 \\
2028 & 2,268 \\
\hline Sumber: Analisis, 2019 &
\end{tabular}

Berdasarkan Tabel 4.7 dilakukan perhitungan Analisis prediksi volume Sedimen terbuang, mengacu data volume sedimen terbuang setelah flushing tahun 2009-2018. Dari hasil analisis regresi didapatkan persamaan $\mathrm{y}=163,48 \ln (\mathrm{x})-1242,6$, yang selanjutnya dilakukan untuk memprediksi data volume sedimen dari tahun 20192028.

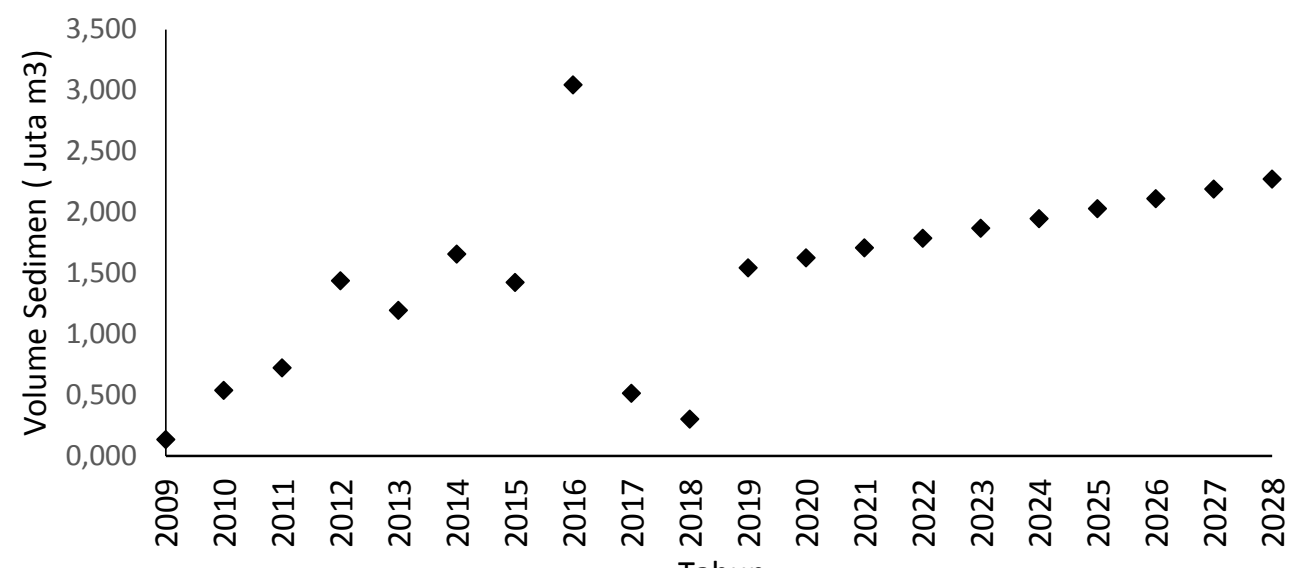

Gambar 4.3 Volume Sedimen terbuang setelah Flushing Tahun 2009-2018 dan prediksi tahun 2019-2028 (Sumber : Analisis, 2019) 
Berdasarkan data volume sedimen yang diperoleh dari PT Indonesia Power UP Mrica pada tahun 20092018 dari jumlah Volume sedimen yang terbuang setelah dilakukan flushing di tahun 2009,2010,2011 dan 2012 mengalami kenaikan karena waktu pelaksanaan flushing mengalami peningkatan yaitu sebesar 435,1058,1597 dan 2290 menit. Pada tahun 2013,2014,2015 dari jumlah volume sedimen yang terbuang setelah di lakukan flushing mengalami naik turun karena dari jumlah waktu pelaksanaan flushing di setiap tahunnya tidak menentu.

Di tahun 2016 dari jumlah volume sedimen yang terbuang setelah dilakukan flushing mengalami peningkatan yang begitu besar karena pada saat pelaksanaan flushing diperoleh waktu terlama yaitu 7098 menit, sedangkan pada tahun 2017,2018 dari jumlah volume sedimen yang terbuang setelah dilakukan flushing mengalami penurunan jumlah waktu flushing dari waktu 1509,1140 menit.

Tabel 8. Volume Air terbuang setelah Flushing Tahun 2009-2018 dan prediksi tahun 2019-2028

\begin{tabular}{cr}
\hline Tahun & $\begin{array}{r}\text { Volume Air } \\
\text { Juta }\left(\mathrm{m}^{3}\right)\end{array}$ \\
\hline 2009 & 7,308 \\
2010 & 17,765 \\
2011 & 26,389 \\
2012 & 38,600 \\
2013 & 33,516 \\
2014 & 25,497 \\
2015 & 10,510 \\
2016 & 119,065 \\
2017 & 25,351 \\
2018 & 19,152 \\
2019 & 50,445 \\
2020 & 53,654 \\
2021 & 56,861 \\
2022 & 60,067 \\
2023 & 63,271 \\
2024 & 66,474 \\
2025 & 69,675 \\
2026 & 72,875 \\
2027 & 76,073 \\
2028 & 79,269 \\
\hline Sumber $:$ Analisis, 2019 &
\end{tabular}

Berdasarkan Tabel 4.8 dilakukan perhitungan Analisis prediksi volume Air terbuang, setelah flushing dari 2009-2018 sebagaimana terlihat di Gambar 4.4 di bawah ini.

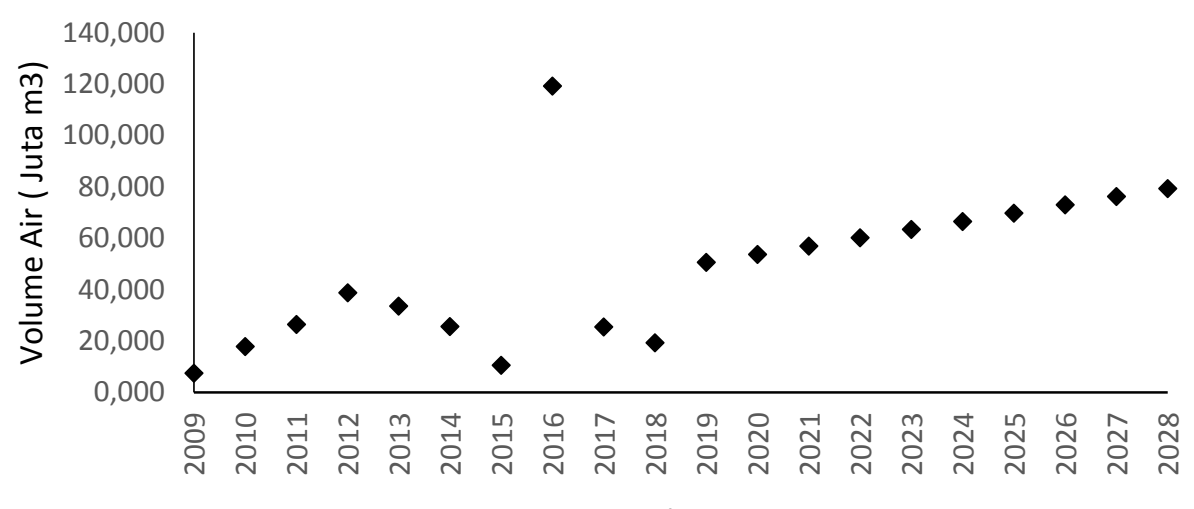

Tahun

Gambar 4.4 Volume Air yang terbuang setelah dilakukan Flushing dari Tahun 2009-2018 dan hasil prediksi dari tahun 2019-2028 (Sumber : Analisis, 2019)

Berdasarkan data volume air terbuang yang diperoleh dari PT Indonesia Power UP Mrica pada tahun 2009-2018, Volume air yang terbuang setelah dilakukan flushing di tahun 2009,2010,2011 dan 2012 mengalami kenaikan karena waktu pelaksanakan flushing mengalami peningkatan sebesar 435,1058,1597 dan 2290 menit. 
Pada tahun 2013,2014,2015 dari jumlah volume air yang terbuang setelah di lakukan flushing mengalami penurunan karena dari jumlah waktu pelaksanan flushing terus menurun di setiap tahunnya yaitu di waktu $1995,1460,629$ menit.

Di tahun 2016 dari jumlah volume air yang terbuang setelah dilakukan flushing mengalami peningkatan yang begitu besar karena pada saat pelaksanaan flushing di peroleh waktu terlama yaitu 7098 menit, sedangkan pada tahun 2017,2018 dari jumlah volume air yang terbuang setelah dilakukan flushing mengalami penurunan jumlah waktu flushing dari waktu 1509,1140 menit. Selanjutnya pada tahun 2019-2028 berdasarkan hasil prediksi untuk mengetahui hubungan antara volume sedimen terbuang dan volume air terbuang selama flusing jika dilakukan tahun 2019-2028 sebagai terlihat pada Tabel 4.9.

Tabel 9. Volume Sedimen dan Volume Air terbuang setelah dilakukan flushing dari tahun 2009-2018 dan prediksi dari tahun 2019-2028

\begin{tabular}{|c|c|c|}
\hline Tahun & $\begin{array}{l}\text { Volume Sedimen } \\
\text { Juta }\left(\mathrm{m}^{3}\right)\end{array}$ & $\begin{array}{l}\text { Volume Air } \\
\text { Juta }\left(\mathrm{m}^{3}\right)\end{array}$ \\
\hline 2009 & 0,130 & 7,308 \\
\hline 2010 & 0,536 & 17,765 \\
\hline 2011 & 0,719 & 26,389 \\
\hline 2012 & 1,435 & 38,600 \\
\hline 2013 & 1,191 & 33,516 \\
\hline 2014 & 1,652 & 25,497 \\
\hline 2015 & 1,422 & 10,510 \\
\hline 2016 & 3,042 & 119,065 \\
\hline 2017 & 0,511 & 25,351 \\
\hline 2018 & 0,299 & 19,152 \\
\hline 2019 & 1,541 & 50,445 \\
\hline 2020 & 1,622 & 53,654 \\
\hline 2021 & 1,703 & 56,861 \\
\hline 2022 & 1,784 & 60,067 \\
\hline 2023 & 1,865 & 63,271 \\
\hline 2024 & 1,946 & 66,474 \\
\hline 2025 & 2,026 & 69,675 \\
\hline 2026 & 2,107 & 72,875 \\
\hline 2027 & 2,188 & 76,073 \\
\hline 2028 & 2,268 & 79,269 \\
\hline$\sum$ & 29,986 & 971,817 \\
\hline
\end{tabular}

Berdasarkan Tabel 4.9 volume sedimen dan volume air setelah dilakukan flushing selama 10 tahun dimulai dari tahun 2009-2018 dan setelah dilakukan predeksi selama 10 tahun mendatang dimulai dari tahun 2019-2028 diperoleh jumlah total volume sedimen yang terbuang sebesar 29,986 juta $\mathrm{m}^{3}$ dan volume air yang terbuang sebesar 971,817 juta $\mathrm{m}^{3}$.

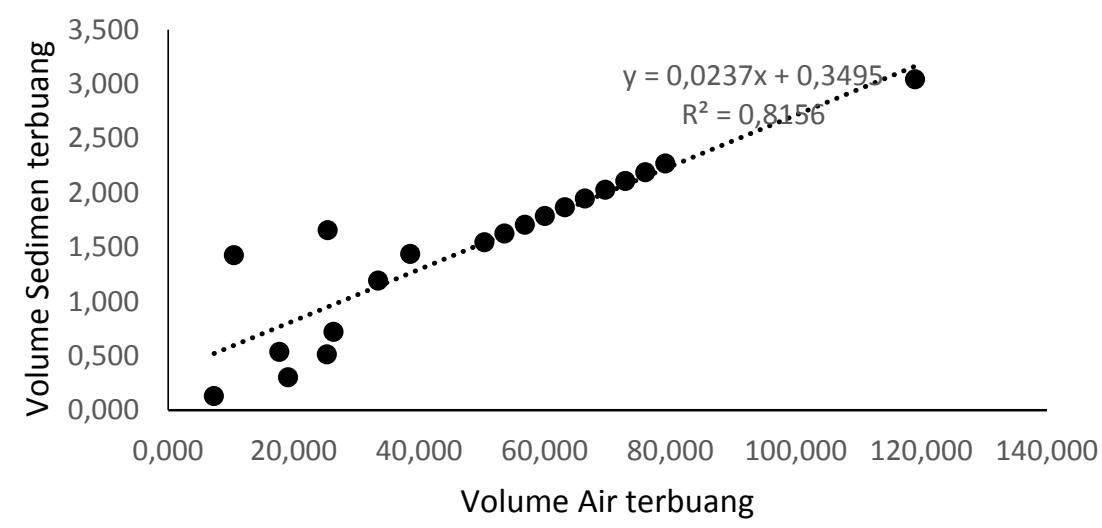

Gambar 4.5 Volume sedimen dan volume air yang terbuang setelah dilakukan Flushing dari Tahun 2009-2018 dan hasil prediksi dari tahun 2019-2028 (Sumber : Analisis, 2019) 
Berdasarkan gambar 4.5 terlihat bahwa semakin tinggi volume sedimen yang terbuang saat dilakukan flushing, volume air yang terbuang juga cenderung meningkat dengan volume yang lebih besar dibandingkan dengan volume sedimen yang terbuang. Mengacu hasil persamaan regresi kedua hal tersebut, tampak dengan nilai $\mathrm{R}^{2} 0,8156$ menunjukkan bahwa terdapat hubungan antara sedimen terbuang dan volume air terbuang pada saat dilakukan flushing.

\section{KESIMPULAN}

Berdasarkan hasil Analisis Pengaruh Pelaksanaan Flushing di Waduk Mrica Terhadap Pengurangan Volume Air Waduk dan Sedimen dari penelitian ini dapat diambil kesimpulan sebagai berikut:

1. Volume sedimen terbuang setelah flushing (2009-2018) dan prediksi (2019-2028) adalah sebesar 29,986 $\mathrm{Juta} / \mathrm{m}^{3}$.

2. Volume air terbuang setelah flushing (2009-2018) dan prediksi (2019-2028) adalah sebesar 971,817 $\mathrm{Juta} / \mathrm{m}^{3}$

\section{DAFTAR PUSTAKA}

[1] Alfianto, A, dan Soewarno 2014, Teknosobo Untuk Mengatasi Sedimentasi Di Daerah Tangkapan Air Waduk, Balai Sabo, Puslitbang Sumber Daya Air, Badan Litbang Pekerjaan Umum, Sleman.

[2] C.D. Soemarto, 1999. Hidrologi Teknik, Erlangga, Jakarta.

[3] Iskahar, 2018. Penanganan Sedimentasi Pada Delta Waduk Dengan Bypass Channel, Ringkasan Disertasi, Universitas Diponegoro: Semarang

[4] Krisetyana, H, 2008, Tingkat Efisiensi Penggelontoran Endapan Sedimen Di Waduk PLTA PB. Tesis. Tidak Diterbitkan. Program Pascasarjana Magister Teknik Sipil. Universitas Diponegoro: Semarang

[5] Marhendi, T, 2013, Strategi pengelolaan sedimentasi waduk, Universitas Muhammadiyah Purwokerto, Purwokerto.

[6] Marhendi, T, 2009, Analisis Umur Fungsi Waduk Mrica, Universitas Muhammadiyah Purwokerto, Purwokerto.

[7] PT. Indonesia Power Unit Pembangkit Mrica. 2007, Laporan Pelaksanaan Penyelidikan Sedimentasi Waduk PLTA PB. Sudirman, Banjarnegara.

[8] PT. Indonesia Power Unit Pembangkit Mrica. 2009, Laporan Pelaksanaan Penyelidikan Sedimentasi Waduk PLTA PB. Sudirman, Banjarnegara.

[9] PT. Indonesia Power Unit Pembangkit Mrica. 2010, Laporan Pelaksanaan Penyelidikan Sedimentasi Waduk PLTA PB. Sudirman, Banjarnegara.

[10] PT. Indonesia Power Unit Pembangkit Mrica. 2016, Laporan Pelaksanaan Penyelidikan Sedimentasi Waduk PLTA PB. Sudirman, Banjarnegara.

[11] Qing Gu, dkk, 2014, Identification and Assessment Of Potential Water Quality Impact Factor for Drinking-Water Reservoir, Universitas Zhejiang, Cina.

[12] Sri Harto Br, 1981. Mengenal Dasar Hidrologi Terapan, Keluarga Mahasiswa Teknik Sipil, Yogjakarta.

[13] Soewarno, 1995. Hidrologi Aplikasi Metode Statistik Untuk Analisa Data, Nova, Bandung.

[14] Suroso, 2007, Model Pengendalian Sedimentasi Waduk Mrica Dengan Fluidasi, Universitas Jendral Sudirman, Purwokerto.

[15] Suripin, 2004. Sistem Drainase Perkotaan yang Berkelanjutan. Yogyakarta: Andi Offset.

[16] Talebbeydokhti, N dan A, Naghshineh, 2004, Flushing Sediment Through Reservoirs, Shiraz University, I. R. of Iran.

[17] Triana Putra, S, 2018, Perbandingan Umur Waduk Mrica Dengan Dan Tanpa Aktivitas Flushing, Skripsi. Tidak Diterbitkan. Program Studi Teknik Sipil. Universitas Muhammadiyah: Purwokerto. 
